\title{
The Role Of NGOs In Community Development In Balochistan
}

\author{
Siraj Bashir \\ Department of Social Work \\ University of Karachi
}

\begin{abstract}
Community Development (CD) is an approach aimed at improving the quality of life of the community. The approach for improvement can be achieved through a number of ways and organizations which includes, the Governmental and Non-Governmental Organizations (NGOs). NonGovernmental Organizations (NGOs) "a private organization that pursue activities to reduce suffering, promote the interest of the poor, protect the environment, provide basic social services or undertake community development". This paper discusses the role and contribution of NGOs towards development in Balochistan. NGOs have several projects, programs and roles which support people to bring development in communities. In addition, NGOs mobilize the communities to be self-dependent. The study includes interviews, document analysis and field studies with staffs and the beneficiaries of NGOs. The study helps the communities to find out their own problems and solve them according to their own local resources. Recommendations made as to the best practices of community development programs for NGOs to improve the living standard of people in province of Balochistan.
\end{abstract}

Keywords: Community Development, Non-Governmental Organizations, Social Change.

$$
\begin{aligned}
& \text { تلخيص }
\end{aligned}
$$

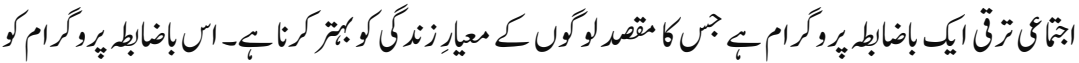

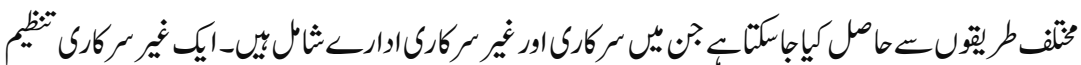

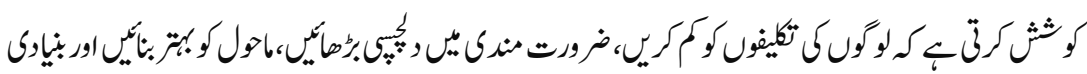

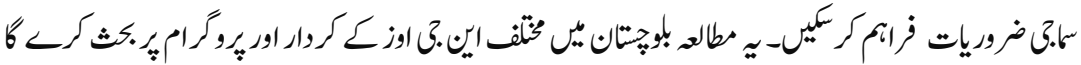

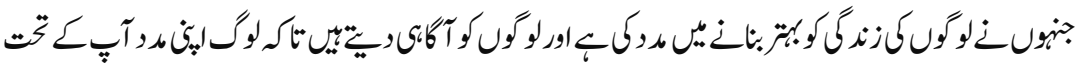

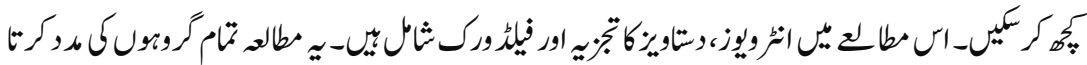

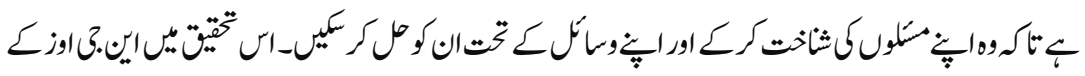

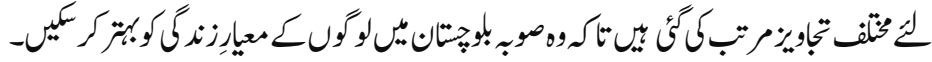

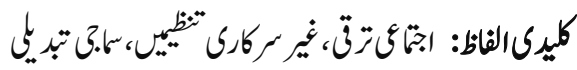




\section{Introduction}

Community Development is an approach to bring about changes in whole community. These changes are actually planned at development of the community. It involves all people, particularly of the areas in the development activities. Community development can provide opportunities to local people to improve the socio-economic condition and also use the existing resources in better way. Community development is defined as "a participatory people centered process that involves bring together, mobilizing or organizing people, keeping them together and enabling them to work together to address their need and issues and thus to facilitate their own, their communities' and society's comprehensive development as the social approach"(Powar,2014).

According to United Nations, community development as the process by which the efforts of the people themselves are united with those of governmental authorities to develop the economic, social and cultural condition of whole communities, to integrate these communities into the life of the nation and to enable them to contribute fully to national progress (United Nation 1956). The concept of community development is referred in terms of community participation, community empowerment and community capacity (Jones, 1982). Thus community development process comprised into two main aspects. First, the participation by the people themselves in attempts to develop their standard of living with as much dependence as possible on their self initiative and second, the provision of technical and social services in ways which promote initiative, self help and joint understanding (Kenny, 1946).

The idea of community development has indicated numerous things to several people. It has been related by some as umbrella term for all types of socioeconomic development programs at the local community. For many other people, it has intended the representation of the local community on the programs planning and implementation at local level. According to Ferrinho (1980), it is the social movement, which happens when somebody, representing the significances of human development and people's felt needs, encourages the local community as a part of action. Similarly, Fitzgerald (1980) says that the term 'community development' has come into world agencies usage to bring the planned and organized changes by people self-efforts to get better the economic, social and cultural conditions of communities.

Community development as a voluntary participation of local community individuals in a systematic process to bring some desirable improvements, especially health, education, housing, recreation in the targeted community. These efforts give a clear direction to strengthening community structure for human well-being. As Maimunah Ismail (2001) mentioned. Community development is 
a process of activities at community level that are planned and organized movements in a particular way so as to improve the standard of life the community as means of social, economy, culture and environment through initiatives and functioning participation and with minimum external help.

Community development is now identified as a dominant practice in social development. Community development practices generate social capital, they contribute to the development of active citizenship and they provides alternative to passive welfare (Gaik, 1981). Community development deals with new issues, but many of its precepts are based on ideas that go back to antiquity. As Campfrens (1997) stated that these ideas emphasize that human can and must contribute collectively to the way a society is run, through participating in decision making, feeling a sense of belonging to the group and having respect for all other human beings.

Pearce (2000) recommended that community development approach contains three key parts: collective empowerment, collective leadership and leading change through dialogue. It's need of time to use community development approach at rural areas as well as urban areas where local people should be involved in all stages such as need assessment, planning and implementing the programs.

In this regard, we can say that community development process may be carry out for various purposes:

- To improve the different sectors of community such as health, education, housing, recreation and so forth.

- To motivate community to prepare community based plans to solve their issues.

- To strengthen the capacities of local communities to identify their resources and interests

- To develop community leaders

- To build a understandable relationship and cooperation among community individuals

- To develop functioning community groups and organizations

However, community development has been considered as a method, a process and a program. It needs a number of planned interventions to achieve its purposed aims. These planned interventions may be taken for a single problem of the community or can focus on a number of issues of that community. For instead, these programs can be related to education, health, housing, nutrition, recreation, agriculture and the same (Phillips, \& Robert, 2008).

The approach for improvement can be achieved through a number of ways and organizations which includes, the Governments and Non-Government 
Organizations (NGOs). Non-Government Organizations (NGOs) "a private organization that pursue activities to reduce suffering, promote the interest of the poor, protect the environment, provide basic social services or undertake community development" (Rahamato, 2002). NGOs and civil society are the main initiators of development and development projects within the countries that they are involved in. NGOs are voluntary institutions that play a significant role in community development and poverty alleviation. International and local NGOs provide services by raising funds, engaging in different relief and development activities, whilst a number of them carry out advocacy programs within the society (Thomas, 1999).

The origin of Non-governmental organizations( NGOs) in Pakistan goes back to partition 1947, when British India was divided into two states Pakistan and India .At that time, many voluntary organizations were formed to provide humanitarian aid to refugees pouring into the newly established country. At early, first few years of Pakistan, many of the NGOs consecrated on rehabilitation and basic services such as health, education, housing and etc.

In Pakistan, NGOs are more active civil society organizations that provide assists to a number of communities to identify their problems and try to improve their quality of life. Non-governmental organizations (NGOs), are the main development actors, which have played an indispensable role in Pakistan for socio-economic development. A number of NGOs are working for the areas of development, which includes, health, education, housing, etc. While some other NGOs are working for social rights, human right, women rights, children rights, etc (Alam, 2008).

Non-Governmental organizations, are known as development actors who can contribute to the promoting of cross-cutting social links and networks which might form the basis for collective action and increased level of democratic participations. NGOs have a great credit in organizing local people at the grassroots can therefore be viewed as strengthening social capital, a role that may complement the delivering of services (Khalid, 2013). However, there is a great trend to involve local communities in development projects. This paper discusses on the role and contribution of NGOs towards development in Balochistan. NGOs have several projects, programs and roles which support people to bring development in communities. In addition, NGOs mobilize the communities to be self-dependent. It helps the communities to find out their own problems and solve them according to their own local resources.

\section{Study Area}

The focus of this study is Balochistan province of Pakistan. Balochistan is one of the four provinces of the Islamic Republic of Pakistan. Balochistan was 
established as a separate province in its present form in 1970. Balochistan, province of Pakistan is by far the largest in size and the smallest in population. The Province covers 34.7 million hectares, almost $44 \%$ of the country's land area, with a population of about 8 million people (12 persons per sq. $\mathrm{km}$.). The province is located in South-Western $(220 \mathrm{~N}$ to $320 \mathrm{~N}$, 660E to $700 \mathrm{E})$ Pakistan. About $80 \%$ of the area can be classified as inter-mountainous. The remaining $20 \%$ consists of flood plains and coastal plains (GoB, 2006).

The Province is divided into 30 districts. The province is headed by a Chief Minister who is elected every five years. The districts are headed by the Deputy Commissioner. The literacy rate is $26.6 \%$ with that of males to females being $36.5 \%$ and $15.0 \%$ respectively. The districts in the province are: 1 . Awaran 2. Bolan 3. Barkhan 4. Chagai 5. Dera-Bugti 6. Gawadar 7. Jafferabad 8. Jhal Magsi 9. Killa Abdullah 10. Killa Saifullah 11. Kohlu 12. Kharan 13. Kalat 14. Khuzdar 15. Kech 16. Lasbela 17. Loralai 18. Mastung 19. Musakhail 20. Nushki 21. Nasirabad 22. Panjgur 23. Pishin 24. Quetta 25. Sibi 26. Sherani 27. Washuk 28. Ziarat 29. Zhob 30. Gandawa (GoB,2015)

\section{Method of Study}

The international and national NGOs were selected for this study. Beneficiaries belong to different NGOs were selected through pre- structured questionnaire from Quetta, Kalat, Nasirbad and Makran divisions. Sample size was 100 respondents. The main objective of this study relate the roles and contributions of Non-Governmental Organizations in community development, the respondents were asked to recognize, the impact of NGO in the socio-economic development of their communities. Secondly the respondents were asked to comment about NGOs contribution towards enhancing their living standard as well as their expectations from NGOs. Thirdly, they were asked to explain the impact of the project implemented in their community. A conscious effort was made to recognize the roles and contributions of NGOs in Balochistan. Both qualitative and quantitative method were used to collect general and focused data and conclusion. The purposive and convenience techniques of non-probability sampling method were applied.

\section{Results and Discussions}

\section{Non-Governmental Organizations and Community Development}

In this study, it was observed that a number of NGOs are working in different areas on several projects and programs in the province. All NGOs are attempting to improve the socio-economic condition of the people in their targeted areas. The findings also showed that majority of NGOs in Balochistan have their operational 
base point in Quetta city, which is the province capital. NGOs are major implementer of community development program in the province. The majority remain poorly developed and require continuous support to exist. They need the help of Government and friends for getting funds. NGOs are implementing a range of community development programs such as education, health, water and sanitation awareness, disaster environment protection, women and girls rights, child labours, human trafficking and skills development.

This study showed that, most NGOs depends on donation and funding from international organizations such as USAID, European commission, World Bank and etc for the implementation of their community development projects and programs. A huge number of NGOs were similarly found to have their activities stopped, because of lack of funds from international and national donors. All donor organizations have showed great interest in civil society organizations (CSOs) and believed that the NGO are more trustable in terms of competence, justice and impact. According to donors organizations Government bureaucracies are corrupt, incompetent, and unresponsive (Rahmato 1991). And there have less chances to achieve community development programs targets and purposes.

Literature have shown that the community development programs (NGOs interventions) have contributed and impacted on a considerable number of Balochistan people, discussing on several aspects of them. For the purpose of this study, importance would be located on the interventions of selected NGOs and funding agencies. The NGOs includes United Nations Development program (UNDP) Pakistan, National rural support program (NRSP) Pakistan, Balochistan rural support program (BRSP), Shirkat Gah women Resource center, Strengthening Pakistan Organization, Pakistan Poverty Alleviation, USAID, Mercy corps Pakistan ,Aurat Foundation, Hands Pakistan, RWF-Root work Foundation Pakistan, GIZ Pakistan, Innovative development organization, Makran Resource center, Mari stop society, People Primary Health Initiate ,Taraqi Foundation ,Council for Community Development, Catholic Relief Services and NCHD. 
Table: 1

Profiles of respondents $(\mathrm{N}=100)$

\begin{tabular}{|c|c|c|}
\hline Respondent characteristics & Number & Percentage respondents \\
\hline Male & 50 & $50 \%$ \\
\hline Female & 50 & $50 \%$ \\
\hline \multicolumn{3}{|l|}{ Education } \\
\hline Secondary & 41 & $41 \%$ \\
\hline College/University & 29 & $29 \%$ \\
\hline Without formal education & 20 & $20 \%$ \\
\hline \multicolumn{3}{|l|}{ Age } \\
\hline 16-24 years old & 14 & $14 \%$ \\
\hline $25-34$ years old & 38 & $38 \%$ \\
\hline $35-44$ years old & 38 & $38 \%$ \\
\hline $45+$ years old & 10 & $10 \%$ \\
\hline \multicolumn{3}{|l|}{ Occupation } \\
\hline Presents & 39 & $39 \%$ \\
\hline Employed & 51 & $51 \%$ \\
\hline Unemployed & 10 & $10 \%$ \\
\hline \multicolumn{3}{|l|}{ Division } \\
\hline Quetta & 25 & $25 \%$ \\
\hline Kalat & 25 & $25 \%$ \\
\hline Nasirabad & 25 & $25 \%$ \\
\hline Makran & 25 & $25 \%$ \\
\hline
\end{tabular}

Source: Filed survey, June, August, 2015

\section{Contributions of NGOs in Balochistan}

Deprived on many fronts, women figure a major marginalized part of society. As Shirkat Gah and Aurat Foundation represents the disadvantaged and implemented a number of projects for women welfare. They worked in different areas of Balochistan of women socio-economic empowerment. The both organizations mobilized women's groups, which involved motivating men as well as women in Balochistan; and build the capacity of the women organizations through advocacy, seminars, trainings and social action programs.

2008-2011, Shirkat Gah women Resources Center, has implemented project "Women Empowerment in Muslim context" in district Jaffarabad and Nasirabad through this project nearly 2000 women empowered. This project created a great awareness in women communities about their rights. Awareness created among women about their all rights as equal citizen and their role in the political process and decision making. Women mobilized and sensitized about issues like gender equality, women rights, human rights, gender based violence and sexual harassment. They became active to participate in the political process and 
decision making in district, provincial and national level. Shirkat Gah has empowered thousands of women, some of them are now fully independent in their respective polities and businesses. They both organizations are working last 20 years in the training and empowerment of women's, relating several aspects of life such as sexuality, education, leadership, skill development, legal awareness and so forth in Balochsitan (Shirkat Gah, 2012).

Innovative Development Organization with the collaboration of Catholic Relief Services implemented a project on "Education, Skills and Protection for Afghan Refugees and Host Communities". This project addressed two key challenges in refugee host areas of Quetta District: children's lack of access to quality primarylevel education and women's lack of skills for income generation. Combined, they created a situation in which a) refugees do not have the education and skills to thrive during their temporary stay in Pakistan or eventual repatriation and b) Pakistani communities have constrained livelihoods options and a limited ability to host Afghans.

IDO provided quality primary-level literacy and numeracy education to 300 outof-school children (150 girls, 150 boys). This education was specifically designed to prepare students for entry into the 12 Afghan private primary schools in Quetta, where they received an education recognized in Afghanistan. The Education and Skills Centers established also played a crucial role in providing women with skills to increase their incomes. IDO offered a skills development program that reached 210 refugee women and 90 host community women during this project. The exact skills was based on women's interests and the findings of a Pakistan and Afghanistan market research study.IDO first mobilized male community members to ensure their support for women's participation in the project and that women were the mobility to visit the center and the market (IDO, 2014).

A number of NGOs in Balochistan are working in emergency, rehabilitation and relief sector. In the history of Balochistan natural disaster has remained the telling sign post viewing the vivid picture of the nation that how much the nation is paralyzed by the devastating wrath of the nature whether it is in the form of earthquake, drought, famine or flood.

In 2008 the Flash Flood which hit the Kohlu, Bolan, Sibi, Naseerabad \& Jaffarabad districts of Balochistan with the heavy torrential consistent rainfall washing out the complete tesil of tali and making its way to Naseerabad effecting the tehsils of Dera Murad Jamali, Tamboo, Baba Kot leaving behind its dreadful scares in the affected areas. The flood which was resulted due to torrential/flash rains affected the aforementioned districts where it caused extensive damage to houses, standing corps, orchards, livestock and water supply schemes affecting 
thousands of people and settlements while cutting and damaging road networks, causing a number of death and several injured (PDMA, 2015).

Provision of the emergency relief and shelter to the flood affected families has emerged as basic need so, a number of NGOs included Strengthening Participatory Organization, Balochistan Rural support Program, Council for Community Development and Innovative Development Organization in collaboration with district and province government, provided relief to effected communities in emergency. Secondly the said NGOs also construed 10,000 houses with the support of International donors (BRSP, 2013).

Civil society plays a fundamental role in voicing people's opinions and questioning powers; it represents politics of consent, while the state represents politics of domination. Thus, SPO implemented a project to strengthen civil society to provide solidarity to community actions. Through this project, the organization strengthened networks of development organizations in Balochistan to promote dialogue and collaboration and encourage participatory approaches to development on a broader level.

Strengthening Balochistan Civil society, SPO worked actively on various issues; disseminated information and organized dialogues on gender equity, human right and legal rights; and initiated right-based advocacy. Their most prominent impact was felt in the events surrounding local elections in the country: civil society participated vigorously in provincial and national dialogues to assist the government in finalizing the Devolution of power plan, and mobilized communities to increase women's participation in elections (SPO, 2010).

National Rural Support Program (NRSP) implemented "Balochistan Education Support Program" with partnership of Balochistan Education Foundation (BEF) during 2008-2013 in four districts of South West Region of Balochistan i.e. Kech, Gwadar, Panjgoor and Awaran. NRSP established 56 community schools in rural areas where communities were assigned to enroll 20 students in each school. In the targeted region the enrolment ration of girls was $46 \%$ against $40 \%$ which almost reached to the benchmark. At end of the project, enrolment per school was reported 42 students per school which reflects higher retention rate in the target schools. Overall annual students' attendance average was $90 \%$ against $70 \%$ target and teacher annual attendance average was 93\% against not less than $90 \%$. Parent Education Committees played a key role to increase enrolment of children .Parent were very keen to send their children in these schools (NRSP, 2014).

National Commission for Human Development started its literacy program in Balochstan in 2002. NCHD during the period of 2012-13 has established 18,624 literacy centers in Balochistan and made 390,624 people literate. Through this 
intervention NCHD has significantly contributed 5\% literacy rate in the overall literacy rate of Balochistan. Majority of the centers were female centers. District wise detail is as under:

Table: 2

Literacy centers in Balochistan

\begin{tabular}{|l|c|c|}
\hline \multicolumn{1}{|c|}{ District } & $\begin{array}{c}\text { No of ALCs } \\
\text { established }\end{array}$ & $\begin{array}{c}\text { No of learners } \\
\text { enrolled }\end{array}$ \\
\hline Musakhel & 90 & 2,154 \\
\hline Sibi & 150 & 3,537 \\
\hline Pishin & 150 & 3,519 \\
\hline Kech & 240 & 4,519 \\
\hline Nouski & 120 & 2,488 \\
\hline Zhob & 240 & 4,966 \\
\hline Kharan & 120 & 2,921 \\
\hline Loralai & 120 & 3,615 \\
\hline Kalat & 180 & 4,065 \\
\hline Ziarat & 120 & 2,452 \\
\hline Jaffarbad & 210 & 2,452 \\
\hline Lasbella & 240 & 5,492 \\
\hline Barken & 60 & 1,215 \\
\hline Gawadar & 60 & 1,526 \\
\hline Total & $\mathbf{2 , 1 6 0}$ & $\mathbf{4 7 , 8 6 5}$ \\
\hline
\end{tabular}

Source: NCHD progress report 2012-13

\section{Recommendations and Conclusions}

It is evident from the main findings of the study that role of NGOs towards the community development in general is very positive and appreciated but a lot of work are needed to be done by the growing number of NGOs in province, for the welfare of whole society. These they can do from side to side an effective mutual programs and strategies with an effective and efficient leadership structure. To be able to achieve community development programs objectives in Balochistan. It is very important to involve local communities in the process of development.

It is very essential; NGOs should be more practical and sensitive towards the goal they have selected to chase and the welfare of those deprived people. There is a great need for research and training for NGO staffs. Equally of huge importance is the vital need for NGOs to look inner, in sourcing funds for its community development programs internally, rather than waiting for the external support of international donors alone. 
The study as a whole concludes that all the community development interventions in the province were completed successfully with the participation of government and local communities and the community participation played a crucial and important role in developmental process. The following recommendations were proposed:

1. Community should be fully aware about the purposes of the community development programs

2. Properly trained young and entrusted people should be given reasonable representation in community development programs for getting higher development interventions.

3. There is need to launch several community development programs at grass root level according to people need to improve their living standard.

4. Women NGOs already working in Balochistan be strengthen, they should include in different programs and training.

5. Federal and provincial Governments should offer the good environment to promote community development programs in Balochistan. Facilities such as education, health services, energy, improving literacy, health and general quality of life are acutely insufficient in the rural areas.

6. There is a need for a monitoring and evaluation mechanism of NGOs so as to make sure that community development programs services reach the needy people in Balochistan. The monitoring and evaluation should be conducted by independent organization.

7. Community development in Balochistan should not be the relate of only Federal, provincial and local governments. It is also necessary that individuals, communities and NGOs and other agencies must be involved in the efforts at eradicating poverty, increasing literacy, providing health facilities and so forth.

\section{References}

Alam, Anwer (2008). Community Development and Social Welfare, New Awan Printers, Peshawar, Pakistan.

BRSP. (2013, November 26). Physical Infrastructure, retrieved from: http://www.brsp.org.pk/index.php.

Compfrens, H. (ed.). (1997). Community Development around the World: Practice, Theory, Research, Training, University of Toronto Press, Toronto. 
Khalid, Mohammad. (2006). Social Work Theory and Practice: With Special Reference to Pakistan. Karachi, Pakistan: Kifayat Academy.

Ferrinho, H. (1980). Towards the Theory of Community Development, South Africa: Juta \& Comp. Ltd.

Fitzgrerald, M. (1980). Urban Community Development in South Africa, Johannesburg: McGraw-Hill.

Gaik, V.R. (1981). Community Development in Indian, Allied Publishers Private Limited, New Delhi, India.

GoB. (2015, March 10). About Balochistan, retrieved from: http://www.balochistan.gov.pk/index.php?option=com_content\&view=arti cle \&id=37\&Itemid $=783$.

Government of Balochistan. (2006). Provincial Disaster Risk Management Plan. Quetta: UNDP publication.

IDO. (2014, May 21). Projects, retrieved from: http://www.ido.org.pk/Projects.

Ismail, Maimunah (2001). Community Development: Distance Education Module: Institute for Distance Education, University Putra Malaysia, Kuala Lumpur.

Jones, G. E. (1982). Progress in Rural Extension and Community Development, John Wiley and Sons, London, UK.

Kenny, Susan (1946). Developing Communities for the Future, CENGAGE Learning, Australia.

NCHD. (2013). Adult Literacy Progress-Progress Report 2012-13.NCHD Publication, Islamabad.

NRSP. (2014). 20th Annual Progress Report. Islamabad, Pakistan: NRSP.

Pawar, Manohar. (2014). Social and Community Development Practice, Saurabh Printers Pvt. Limed, Delhi, India.

PDMA (2015, January 06). Seminar on Natural Disasters, retrieved from: http:/www.pdma.gob.pk/ 
Pearce, J. (2000). Development, NGO and the Civil Society, Oxfam Publication Limited, United Kingdom.

Phillips, Rhonda \& Robert. H. Pittman., (ed.) (2008). An Introduction to Community Development, Taylor and Francis -e-library, New York, USA.

Rahamato, D. (ed.). (2002). Civil Society Organizations in Ethiop. Stockholm, Elanders Gotab.

Rahmato D .(1991). The Concept of Community Development, Community Development as a Process. Columbia, Missouri: University of Missouri.

Shirkat Gah. (2012). Women Empowering Themselves, The Author, Lahore, Pakistan.

SPO. (2010). Profile 2010/2011. Islamabad, Pakistan: SPO.

Thomas Kuby. (1999). Non-Governmental Organizations Work in World BankSupport Project, Oxford Press, Washington, DC., USA.

United Nation. (1956). Popular Participation in Decision Making for Development, UNO Publications, New York, USA.

Siraj Bashir is Teaching Assistant and Ph.D Scholar in the Department of Social Work, University of Karachi. 